\title{
DETECTION OF HYDROCARBON, BY USING ADVANCED WELL LOG TOOLS FOR KAFR EL-SHEIKH FORMATION AT SAPPHIRE FIELD, OFFSHORE NILE DELTA, EGYPT
}

\author{
1- Faculty of Science, Demietta University, \\ 2- Nuclear Materials Authority, Cairo Egypt.
}

Hassan El-Kady ${ }^{1}$, Mohamed Fathy ${ }^{1}$ and Samir Nabil Shehab ${ }^{2}$.

\section{ABSTRACT}

The present work is devoted to study the geologic setting, reservoir characterization and hydrocarbon detection with conventional and advanced well log methods for Kafr El-Sheikh Formation at Sapphire field, Offshore Nile Delta, Egypt. The used wells are Sapphire-Da, Db, Dc, De, Dh and Dq. By using open hole logging tools, advanced logging tool like Modular dynamic tester (MDT), Mud log during drilling and conventional core that analyzed carefully, to detect the clean sandstone and thin bedded sandstone of the study Location.

These basic well log tools (Gamma Ray, Resistivity, Density and Neutron) reflectclean sandstone reservoir with good way, but can't detectthin bedded sandstone reservoir, as a result of their low vertical resolution, this may miss several intervals charged with hydrocarbons during perforation and production from the field.So, we should run advanced tool like the Modular Dynamic Tester (MDT) and analyze conventional core, if found, and the hydrocarbons in Mud log to detect these missed intervals. Also by using the conventional cores and mud logging while drilling.

The results had showed clean sandstone and thin bedded sandstone reservoirsthroughthe advanced well log tools, which identify more than 68\% deep water reserve didn't use beforethis should be takeninto consideration in the future wells, workover wells, excellent distribution of facies in both the static and dynamic models, to increase the hydrocarbon production and life time of producible wells. . The optimum location for forthcoming wells is south west of the field, because it has the best petrophysical parameters. It has high porosity, hydrocarbon saturation, and net to gross, in addition to low shale volume.

\section{INTRODUCTION}

\section{General Outlookon the Nile Delta:}

The Nile Delta has the classical shape of the Greek letter shape "Delta", which was compared by Herodotus in the fifth century. The recent Nile Delta covers about $(50,000$ $\mathrm{km}^{2}$ ) equally, distributed between onshore and offshore areas. (Fig.1).

The Sapphire Field is located at the northwestern margin of the Nile Delta, approximately $90 \mathrm{~km}$ offshore from Alexandria. The field lies at the West Delta Deep Marine Concession (Fig.2). It lies at the interaction betweenLat $32^{\circ} 01^{\prime} 43.192 " \mathrm{~N}$ and long $30^{\circ} 21^{\prime}$ 10.707" E. The Sapphire block comprises approximately $90 \mathrm{~km} 2$ surface area. Gas was encountered in the Pliocene sandstones (Kafr El-Sheikh Formation) of that field. The reservoir consists of a succession of sandstones, claystones and siltstones in a general upward fining succession. Six wells in Sapphire Field are chosen for this study. These are (SapphireDa, Db, Dc, De, Dh and Dq), as shownin (figure 1).

\section{MATERIALS AND METHODS}

The present study is buildup on basic well logs (Gamma-Ray, Density, Neutron and Resistivity), Modular Dynamic Tester (MDT), Mud log and conventional cores. Six wells had been chosen from the Sapphire field(SapphireDa, Db, Dc, De, Dh\& Dq).

\section{Log Data}

The available well log data for the present study are in digitized form the following table shows the available open-hole well logging tools of sixwells studied in this work. The Interactive Petrophysics (Techlog) 3.4 Software was used for the all petrophysical calculations 
and for drawing all figures in this study, which developed by Schlumberger service company.

\section{Workflow of WELL LOGS}

Well logs represent the geophysical recordings of various rock properties in boreholes, and can be used for geological (stratigraphic and structural) interpretations. The most common log types that are routinely employed for facies and petrographical analyses (lithology, porosity and fluid evaluation), and stratigraphic correlations. These log types may be considered 'conventional' as have been used since decades. Well logs have both advantages and shortcomings, relative to what outcrops have to offer in terms of facies data. One major advantage of the geophysical logs over outcrops is that they provide continuousvertical record from relatively thick successions, often in a range of kilometers.

\section{Petrophysical Evaluation of Sapphire Field.}

In this part, we are dealing with the lithologic and petrophysical properties of the encountered reservoir rocks, based on the results of well log analysis carried out for the six chosen wells in the area of study, through to the detectionof the petrophysical parameters (clay volume, effective porosity and water saturation) by,

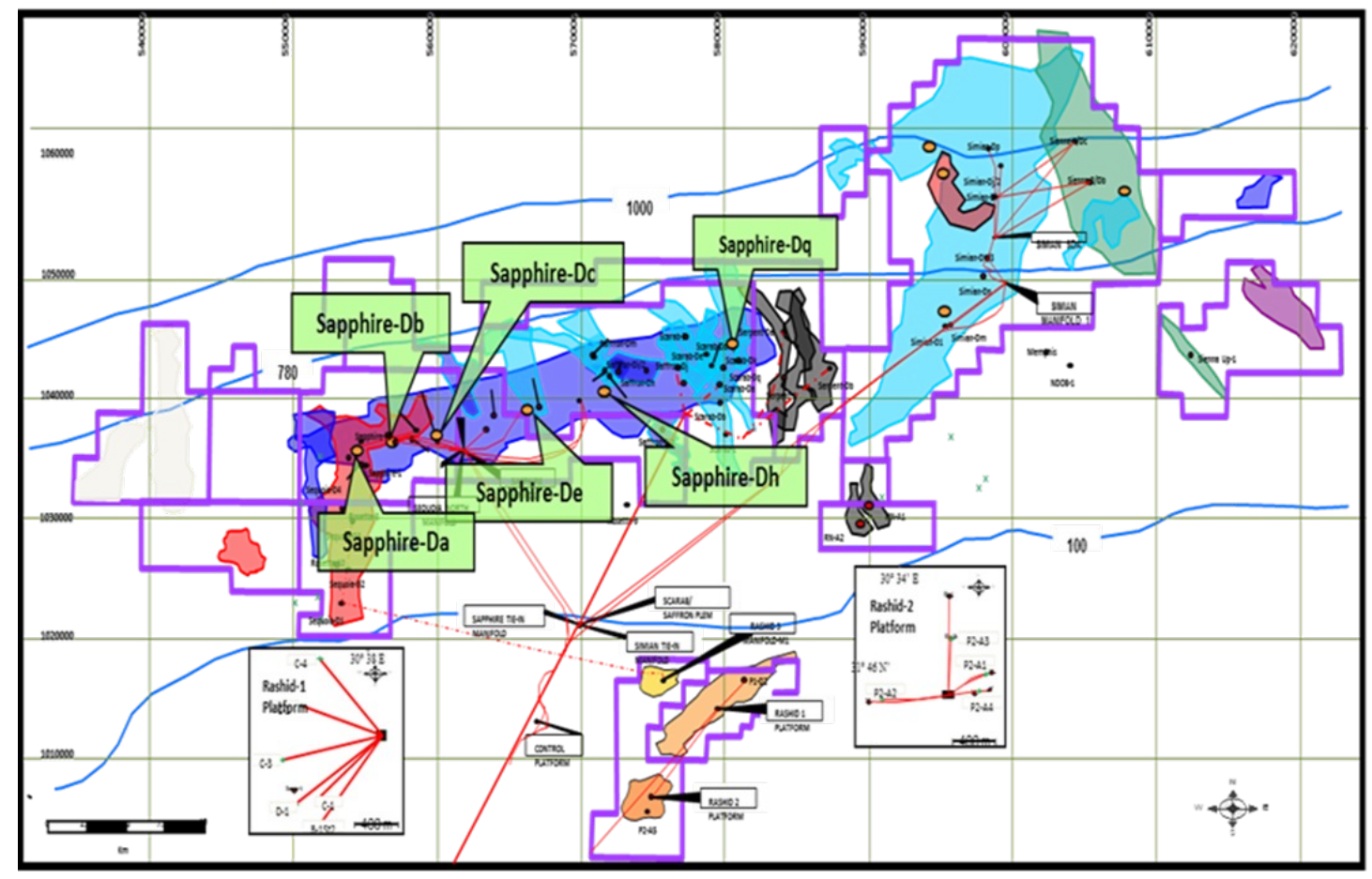

using theTechlog software.

Detection of shale types, petrophysical

Figure 1. Location map of Sapphire Field that contains six wells used in the present study.

Table.1. Direct and indirect measurements of well log tools.

\begin{tabular}{|l|l|l|}
\hline Well Logging Tool & Direct Measurements & Indirect Measurements \\
\hline SP Log & Millivolts & Permeable Zones \\
\hline Gamma ray Log & API units & Shaliness \\
\hline Caliper Log & Hole Diameter & borehole Corrections \\
\hline Density Log & Bulk Density & Porosity and Heavy Minerals \\
\hline Neutron Log & & Porosity \\
\hline Resistivity Logs & Hydrogen Index & Fluid Saturation. \\
\hline MDT & Resistivity & Permeability \\
\hline
\end{tabular}


HASSAN EL-KADY, et al.

advanced tools detect clean and thin bedded sandstone reservoirs, with very high accuracy and show where free fluids, hydrocarbon and permeability are for Production.

Detection of Hydrocarbon duringDrilling by rac Chmomatammoh and rac Motanton sandstone reservoirs basic tools can't catch them as a result of their low vertical resolution, but appears clearly during drilling.

\section{Detection of Thin Bedded Sandstone by Conventional Core}

Table 3. Shows pressure point which had been taken in both conventional and unconventional reservoirs in Sapphire-Da well.

\begin{tabular}{|c|c|c|c|c|c|c|c|c|c|c|c|c|c|c|c|c|c|}
\hline \multicolumn{3}{|l|}{ Well: } & \multicolumn{2}{|c|}{ Sapphire-Da } & \multicolumn{3}{|c|}{ RTE (m amsl): } & \multicolumn{2}{|c|}{22.25} & \multicolumn{8}{|c|}{ BURULLUS GAS COMPANY } \\
\hline \multicolumn{3}{|l|}{ pate: } & \multicolumn{2}{|c|}{ 15-Aug-04 } & \multicolumn{3}{|c|}{ Hole Size (in): } & \multicolumn{2}{|c|}{8.5} & \multicolumn{8}{|c|}{ WIRELINE TEST REPORT - PRESSURE DATA } \\
\hline \multicolumn{2}{|c|}{ Suite No: } & & \multicolumn{2}{|c|}{1} & \multicolumn{3}{|c|}{ Reservoir: } & \multicolumn{2}{|c|}{ Sapphire Sd } & \multirow{2}{*}{\multicolumn{3}{|c|}{ SAMPLE DATA }} & \multirow{3}{*}{\multicolumn{2}{|c|}{$\begin{array}{c}\text { Final } \\
\text { Hydrostatic }\end{array}$}} & \multirow{4}{*}{$\begin{array}{l}\text { Temp } \\
(\operatorname{degF})\end{array}$} & \multirow{4}{*}{ Remarks } & \\
\hline \multirow{3}{*}{$\begin{array}{l}\text { File } \\
\text { No. }\end{array}$} & \multirow{3}{*}{ es: } & \multirow{2}{*}{\multicolumn{2}{|c|}{ DEPTH $(m)$}} & \multirow{3}{*}{$\begin{array}{c}\text { Gauge } \\
\text { Type } \\
\end{array}$} & \multirow{2}{*}{\multicolumn{2}{|c|}{\begin{tabular}{c|} 
Initial \\
Hydrostatic
\end{tabular}}} & \multicolumn{3}{|c|}{ PRETEST DATA } & & & & & & & & \\
\hline & & & & & & & Fmn Pre & ress. & Mob & \multirow{2}{*}{$\begin{array}{l}\text { Min } \\
\text { FP }\end{array}$} & Final & Time & & & & & Tes \\
\hline & & RKB & TVDSS & & psia & \begin{tabular}{|l|} 
ppge \\
\end{tabular} & psia & ppge & $\mathrm{md} / \mathrm{cp}$ & & FP & (secs) & psia & ppge & & & Typ \\
\hline 82 & 1 & 2776.02 & -2732.9 & CQG & 5655.04 & 11.94 & 4476.33 & 9.6 & 1131.7 & & & & 5652.69 & 11.94 & 150 & Excellent pressure test & $\mathrm{N}$ \\
\hline 83 & 2 & 2779.99 & -2736.7 & CQG & 5661.28 & 11.94 & 4477.5 & 9.59 & 1984.1 & & & & 5659.15 & 11.93 & 151 & Excellent pressure test & $\mathrm{N}$ \\
\hline 84 & 3 & 2831.01 & -2785.4 & CQG & 5762.15 & 11.93 & 4492.77 & 9.45 & 127.55 & & & & 5757.56 & 11.92 & 154 & Very Good pressure test & $\mathrm{N}$ \\
\hline 85 & 4 & 2862.03 & -2815 & CQG & 5823.17 & 11.93 & 4603.38 & 9.59 & 354.73 & & & & 5820.33 & 11.92 & 156 & Very Good pressure test & $\mathrm{N}$ \\
\hline 86 & 5 & 2865.01 & -2817.9 & CQG & 5826.41 & 11.92 & 4607.39 & 9.58 & 1096.6 & & & & 5822.99 & 11.91 & 158 & Excellent pressure test & $\mathrm{N}$ \\
\hline 87 & 6 & 2867.02 & -2819.8 & CQG & 5827.26 & 11.91 & 4610.05 & 9.58 & 761.05 & & & & 5825.31 & 11.91 & 160 & Excellent pressure test & $\mathrm{N}$ \\
\hline 88 & 7 & 2875.52 & -2827.9 & CQG & 5846.21 & 11.92 & 4508.52 & 9.35 & 1853.7 & & & & 5843.66 & 11.91 & 161 & Excellent pressure test & $\mathrm{N}$ \\
\hline 89 & 8 & 2877.02 & -2829.3 & CQG & 5846.93 & 11.91 & 4509.17 & 9.34 & 308.86 & & & & 5844.98 & 11.91 & 161.6 & Excellent pressure test & $\mathrm{N}$ \\
\hline 90 & 9 & 2886 & -2837.9 & CQG & 5867.29 & 11.92 & 4514.27 & 9.32 & 108.98 & & & & 5864.19 & 11.91 & 162.8 & Very Good pressure test & $\mathrm{N}$ \\
\hline 91 & 10 & 2888.02 & -2839.8 & CQG & 5868.37 & 11.91 & 4516.83 & 9.32 & 208.67 & & & & 5866.3 & 11.91 & 163.8 & Very Good pressure test & $\mathrm{N}$ \\
\hline 92 & 11 & 2886.02 & -2837.9 & CQG & 5871.26 & 11.92 & 4511.33 & 9.32 & 0.01 & & & & 5868.33 & 11.92 & & WATER IDENTIFICATION & \\
\hline 93 & 12 & 2851.03 & -2804.5 & CQG & 5790.77 & 11.91 & 4498.06 & 9.4 & 149.57 & & & & 5792.82 & 11.91 & 166 & Very Good pressure test & $\mathrm{N}$ \\
\hline 94 & 13 & 2847.45 & -2801.1 & CQG & 5785.16 & 11.91 & 4497.18 & 9.41 & 26.72 & & & & 5786.33 & 11.91 & 165 & Good pressure test & $\mathrm{N}$ \\
\hline 95 & 14 & 2846.53 & -2800.2 & CQG & 5784.24 & 11.91 & 4497.01 & 9.41 & 195.68 & & & & 5784.63 & 11.91 & 164.8 & Very Good pressure test & $\mathrm{N}$ \\
\hline 96 & 15 & 2799.52 & -2755.3 & CQG & 5687.23 & 11.91 & 5005.05 & 10.65 & 367.95 & & & & 5694.19 & 11.92 & & SUPERCHARGED & \\
\hline 97 & 16 & \begin{tabular}{|l|}
2801.22 \\
\end{tabular} & -2757 & CQG & 5697.25 & 11.92 & & & & & & & 5696.73 & 11.92 & & LOST SEAL & $\mathrm{SF}$ \\
\hline 98 & 17 & 2865.03 & -2817.9 & CQG & 5826.54 & 11.92 & 4609.15 & 9.59 & 0.81 & & & & 5825.06 & 11.92 & & DRY TEST & \\
\hline 99 & 18 & 2864.9 & -2817.7 & CQG & 5823.58 & 11.92 & 5823.88 & 12.12 & 22.96 & & & & 5823.28 & 11.91 & & LOST SEAL & SF \\
\hline 100 & 20 & \begin{tabular}{|l|l|}
2867.02 \\
\end{tabular} & -2819.8 & CQG & 5826.77 & 11.91 & & & & & & & 5826.34 & 11.91 & & DRY TEST & \\
\hline 101 & 21 & 2776 & -2732.9 & CQG & 5640.29 & 11.91 & 4478.25 & 9.61 & 235.92 & & & & 5598.98 & 11.82 & 162.5 & Very Good pressure test & $\mathrm{N}$ \\
\hline \begin{tabular}{|l|l|}
102 \\
\end{tabular} & 22 & 2697.5 & -2657.9 & CQG & 5487.61 & 11.92 & 4449.3 & 9.81 & 7.51 & & & & 5488.58 & 11.93 & 158.8 & Fair pressure test & $\mathrm{N}$ \\
\hline 104 & 23 & 2508.52 & -2475.9 & CQG & 5124.34 & 11.97 & 4274.67 & 10.12 & 1204 & & & & 5123.3 & $\mid 11.97$ & 148.6 & Excellent pressure test & $\mathrm{N}$ \\
\hline 105 & 24 & 2381.99 & -2353.9 & CQG & 4867.91 & 11.98 & 4093.13 & 10.19 & 87.77 & & & & 4868.83 & 11.98 & 144.4 & Very Good pressure test & $\mathrm{N}$ \\
\hline
\end{tabular}

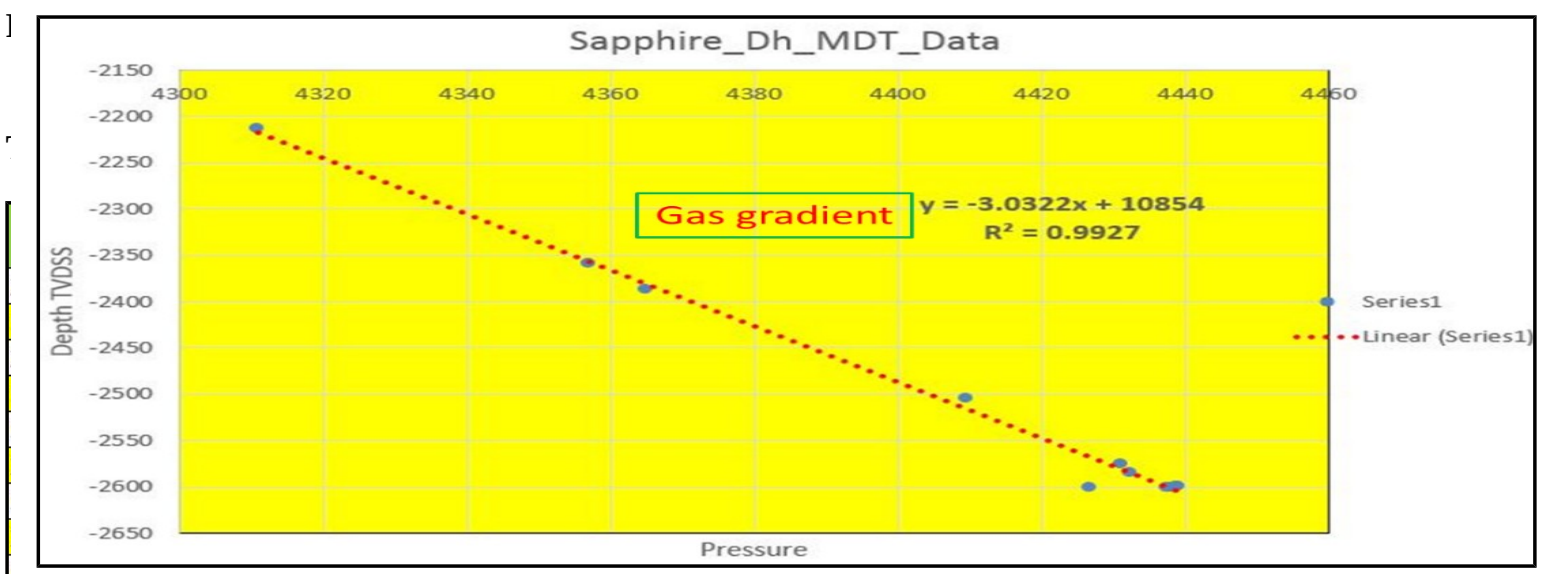

Figure 5. Shows the relation between depth (in meter) and pressure (in psi), which gives the gas gradient in both conventional and unconventional targets of Sapphire-Dh-well. surements and 1e through the in bedded which didn't ), which have ted bythe hole cal plugs had been taken, to make a very accurate lithologic interpretation. 

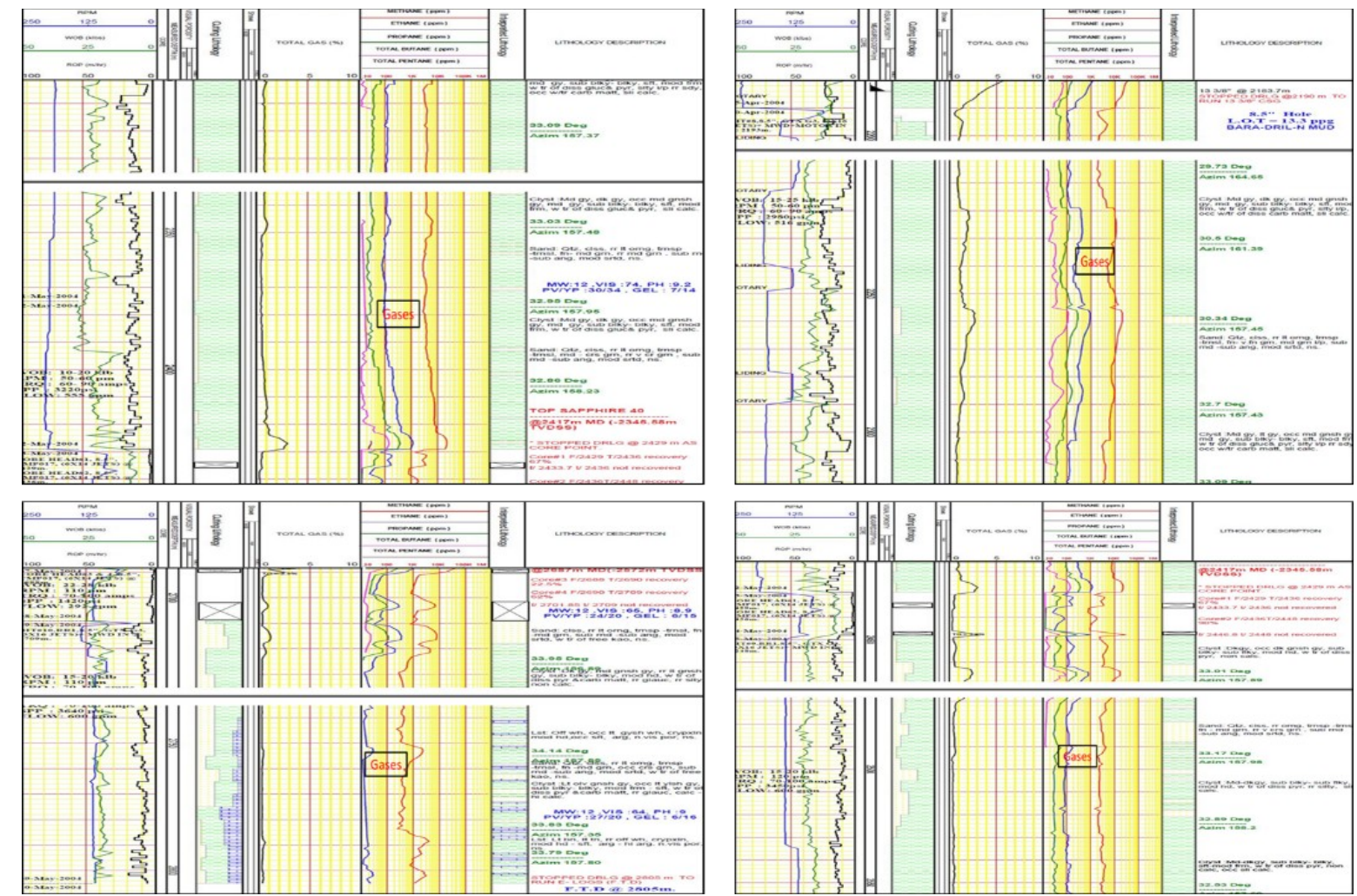

Figure 6. Shows detection of hydrocarbon by gas chromatograph and gas detector during the drilling of Sapphire-Dh well.

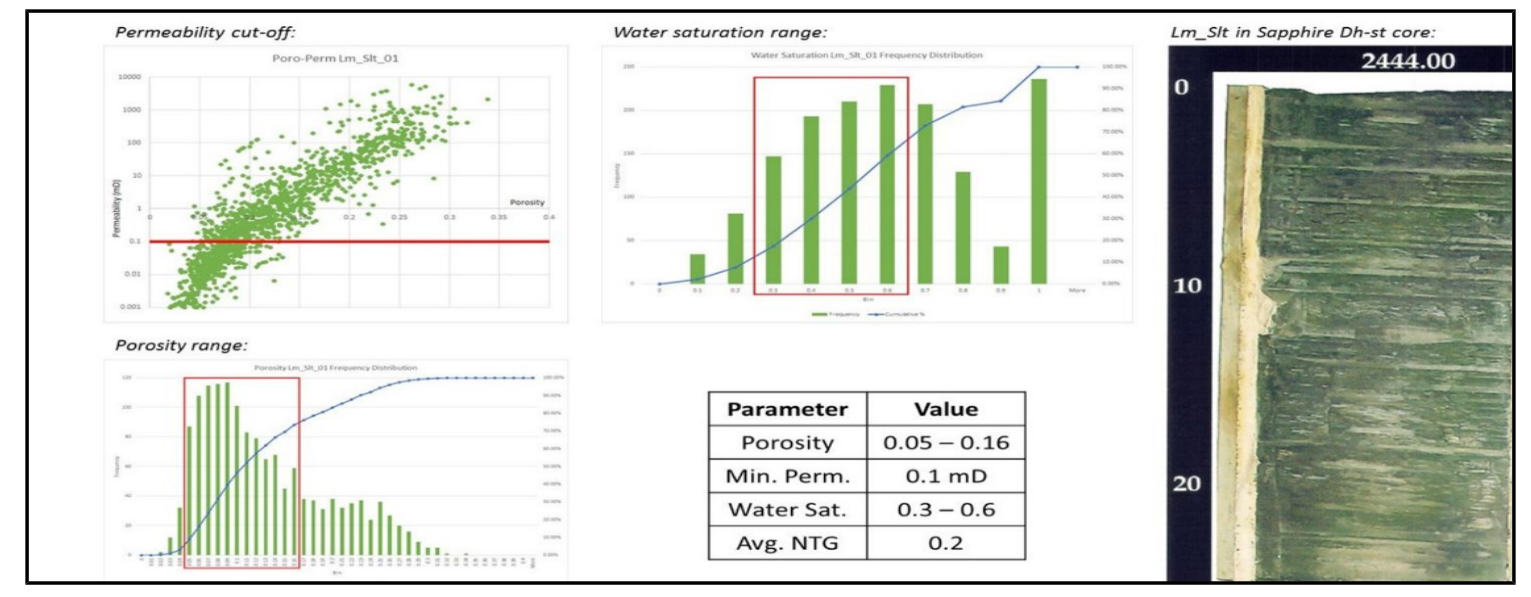

Figure 7. Shows laminated fine sandstone, including the petrophysical parameters (porosity, Permeability, Net to gross ratio and water saturation), porosity ranges from 0.05 to 0.16 . Minimum permeability is $0.1 \mathrm{MD}$, water saturation ranges from 0.3 to 0.6 and net to gross ratio is 0.2 at depth $2444 m$. 
HASSAN EL-KADY, et al.
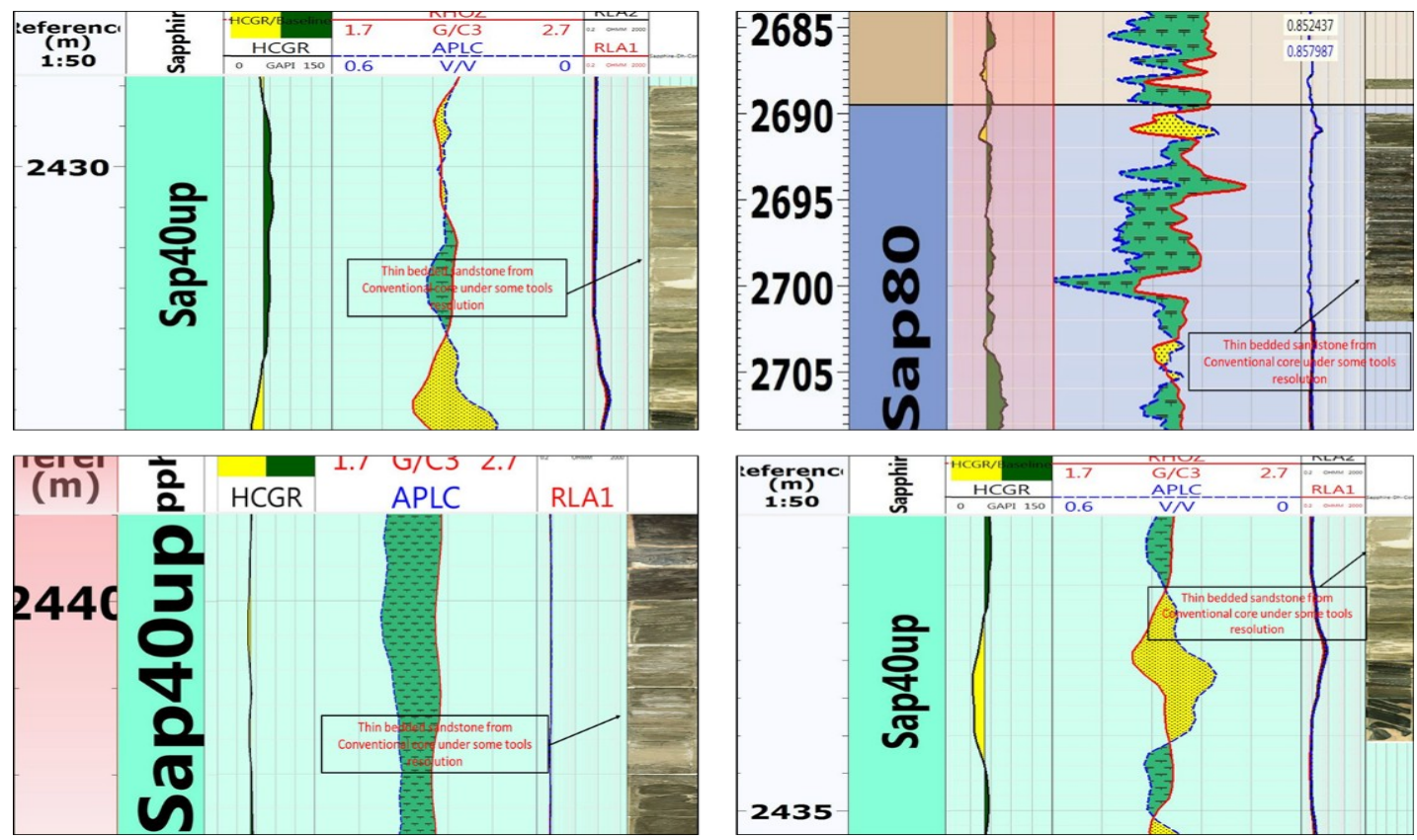

Figure 8. Shows conventional core versus logs at depth (2430m-2704m).
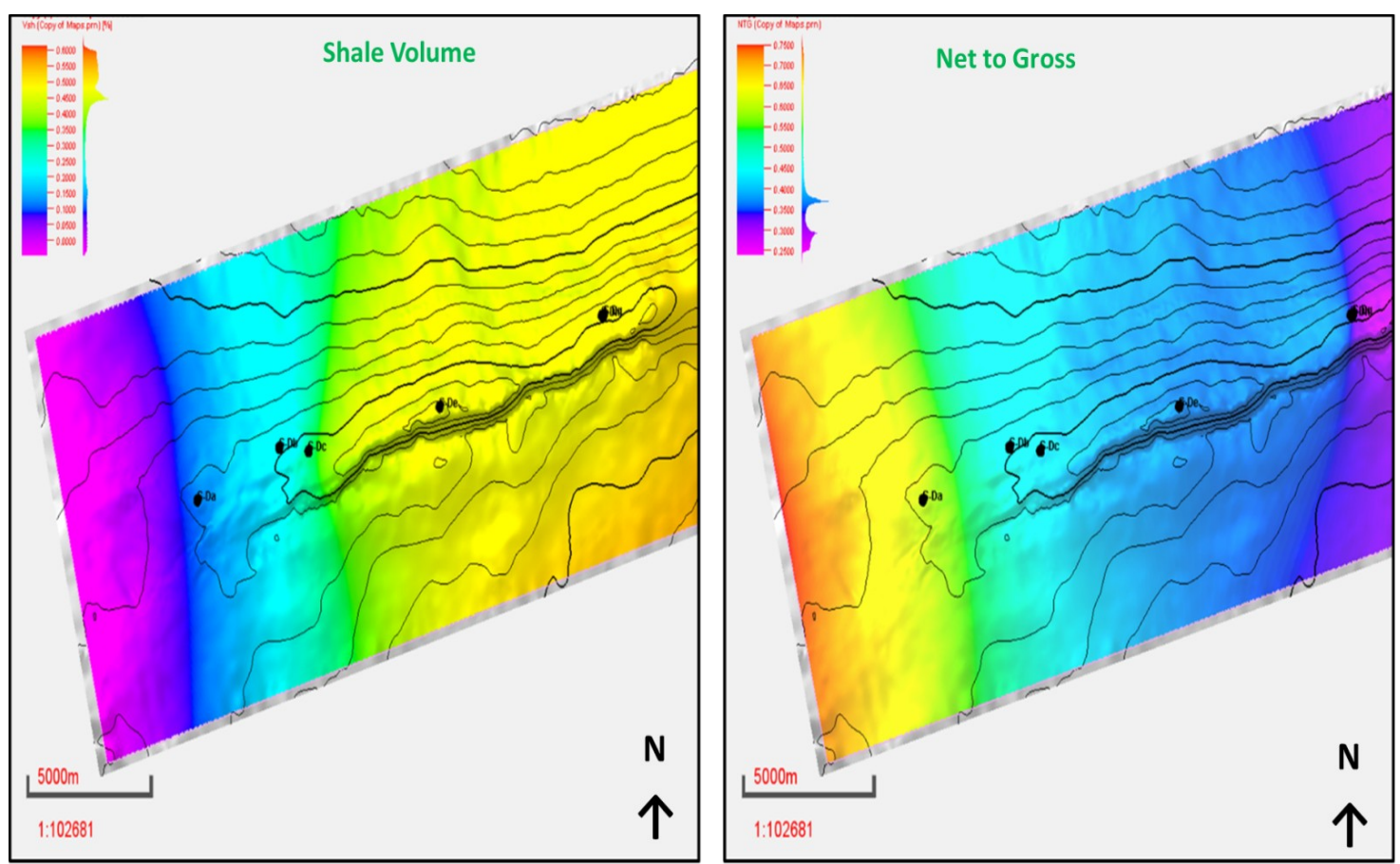

Figure 9.Shows Shale content and net to gross maps. 

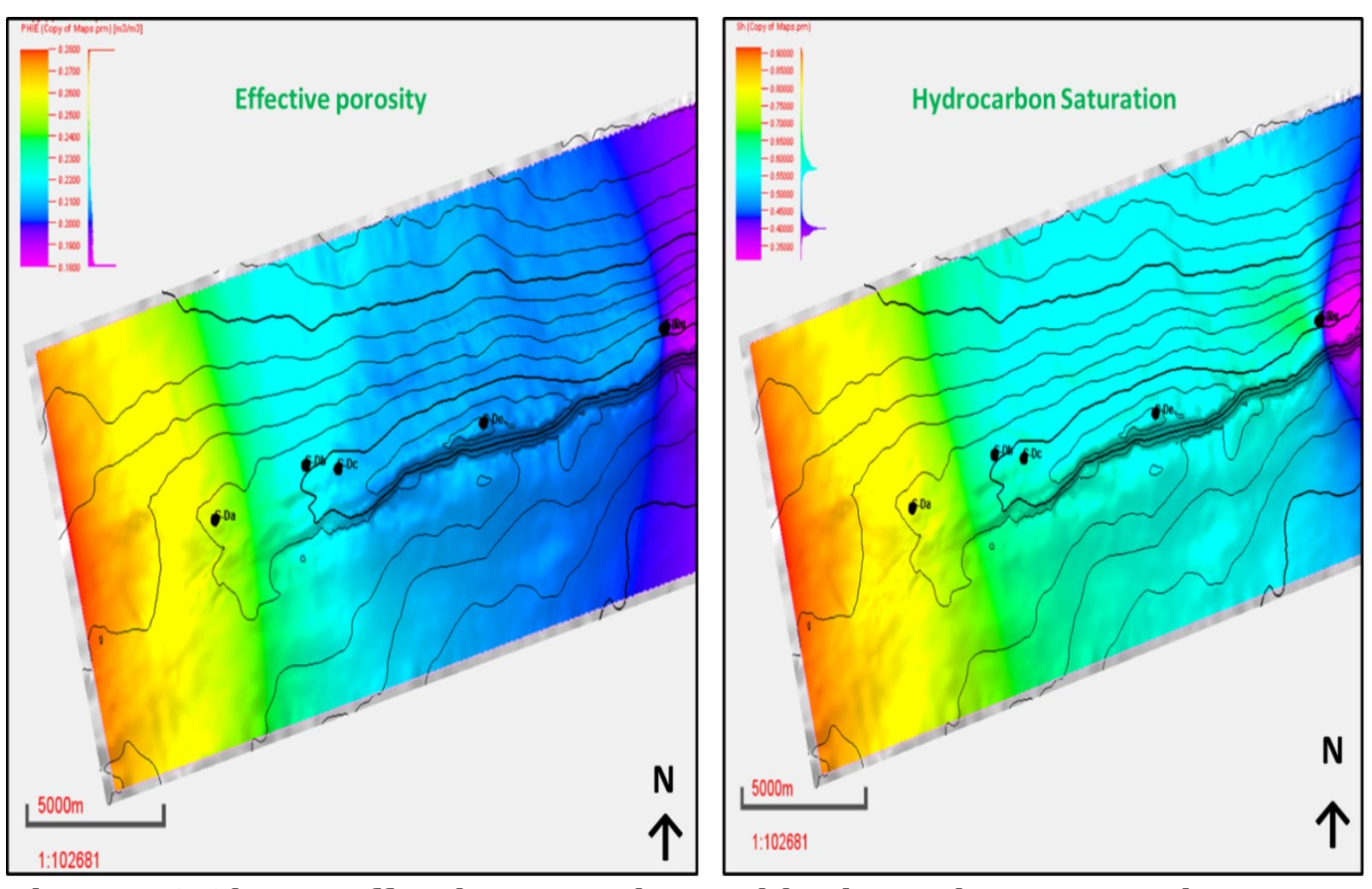

Detecting the amount of gas during drilling by gas

Figure 10.Shows effective porosity and hydrocarbon saturation maps.

\section{CONCLUSIONS}

The present work is devoted to the study of geologic setting, reservoir characterization and hydrocarbon detection through the conventional and advanced methods for Kafr El-Sheikh Formation at Sapphire field, Offshore Nile Delta, Egypt. The used wells are Sapphire-Da, Db, Dc, De, Dh and Dq.This is done through using the basic logging tools and advanced loggingtool, like the Modular dynamic tester (MDT) and Mud log during drilling also the conventional coresare analyzed carefully to detect the clean sandstone and thin bedded Sandstone of the studiedinterval.

These basic tools (gamma-ray, resistivity, density and neutron) reflectclean sandstone reservoir with good quality, but can't catch thin bedded sandstone reservoir, as a result of their low vertical resolution, this may miss several intervals charged with hydrocarbon during perforation and production from the field.So, we should run advanced tool like the Modular Dynamic Tester (MDT) and analyze the conventional cores, if found, and hydrocarbon in Mud log, to detect these missed intervals. chromatograph and gas detector, is a very good indication of both clean and thin bedded sandstone reservoirs. This is because these gases come from the formation, as result of charging with hydrocarbon. In thin bedded sandstone reservoirs, the basic tools can't catch them as a result of their low vertical resolution, but appear clearly during drilling.

By making combination of all the basic logging tools, MDT, Mud logging and conventional cores,we can detect thin bedded sandstone reservoirs clearly and add new reserves toSapphire field didn't appear before.This is through detection of the amount of sands intercalated with shales and their hydrocarbon saturation, these new sands increase the life time of production and understanding Sapphire field in deep.

The results had showed clean sandstone reservoirs and thin bedded sandstone reservoirsthrough the advanced tools, which identify more than $68 \%$ deep water reserve should be takenin consideration in the future wells and workover wells.Excellent distribution of facies in both the static and dynamic models are established to increase the hydrocarbon 
production and the life time of producible wells.. The optimum location for forthcoming wells is south west of the field, because it has the best petrophysical parameters. It has high porosity, hydrocarbon saturation, and net to gross, in addition to low shale volume.

\section{REFERENCES}

Lashin, M., and Morgan, E., 2012. Analysis of well log and pressure data of the gas-bearing sand reservoirs of Kafr El-Sheikh Formation: A case study. EGPC, Cairo, pp. 75-106.

Marten, R., Shann, M., Mika, J., Rothe, S. and Quist, Y., 2004. Seismic challenges of developing the pre-Pliocene Akhen Field offshore Nile Delta. The Leading Edge, V. 23, no. 4, pp. 314320.

Mayall, M., Jones, E., and Casey, M., 2006. Turbidite channel reservoirs key elements in facies prediction and effective development. Marine and Petroleum Geology, v. 23, pp. 821-841.

Othman, A. A. and Fathy, M. 2013.Seismic attribute techniques applied to delineate channel complex in Pliocene age, north Abu Qir Nile Delta, Egypt. Journal of Applied Sciences Research, V. 9, no. 7, pp. 4255-4270.

Raslan, S., 2002. Sedimentology and sequence stratigraphic studies for scarab saffron Field. Ph.D. Thesis, Faculty of Science, Ain Shams University, Cairo, Egypt, pp. 10-43.

Robert, M., and Mark, S., 2004.Seismic challenges of developing the pre-Pliocene Akhen Field offshore Nile Delta. The Leading Edge, April 2004.

Said, K., Farouk, J., Metwalli, I., and Al Arabi, H. S., 2012. Analysis of petroleum system for exploration and risk reduction in AbuMadi/Elqar'a Gas Field, Nile Delta, Egypt. EGPC, Cairo, p.1-10

Samuel, A., Kneller, B., Raslan, S., Sharp, A. and Parsons, C., 2003. Prolithic deep-marine slope channels of the Nile Delta, Egypt. AAPG Bulletin, v. 87, pp. 541-560.

Sehim, A., 2002. Structural architecture and tectonic synthesis of Rosetta Province, West Nile Delta Mediterranean. Egypt, p.18-35.

Sharaf, L.M., 2003. Source rock evaluation and geochemistry of condensates and natural gases, offshore Nile Delta Egypt. Journal of Petroleum Geology, vol.26, no.2, pp.189-209.

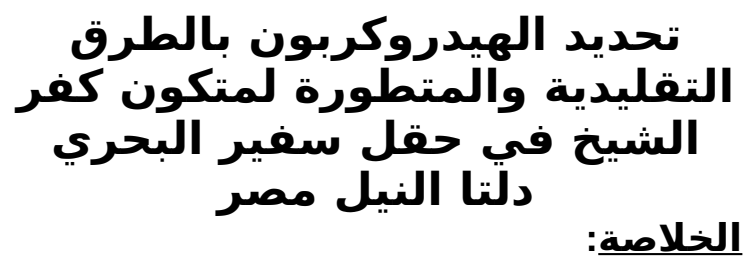

يكرس هذا العمل لدراسة البيئة الجيولوجية وتوصيف الخزان والكشف عن عن المواد

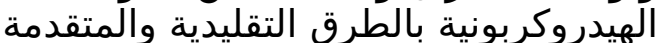

لمتكون كفر الشيخ في حقل الياقوت اليدري في دلتا

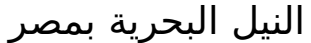

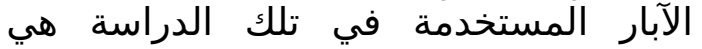

( سفير-دي اي و سفير دي بي ومي و سفير دي سي سي

و سفير دي ايه و سفير-دير سير دي اتش وسفير دي ديري

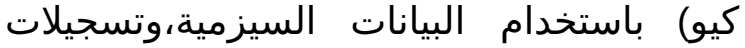
الابار الاساسية والمتقدمة و العاسيات العينات الصخية الصخرية الناتجة من حفر الابار و التتابع الصخرية الصنات خلال

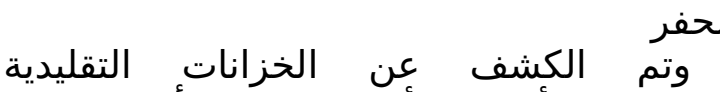
باستخدام الأدوات الأساسية مثل أشنات أشعة جاما،

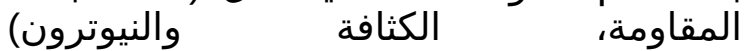

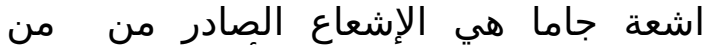
العناصر الموجودة في قشرة الأرض التيعاع تخأليع

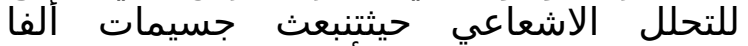
وجزيئات بيتا وجسيمات أشعة أشئنة جاما نتيجة تفككات

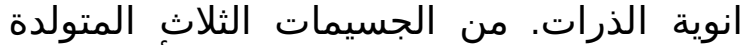
خلال الاضمحلال الإشعاعي الطبيعي، أشعة أشعة جاما هي الوحيدة التي يمكن الإضعا أن تخترق الصيعة الصخور لمسافة ملحوظة الميدة أداة الكثافة توفر قياسات كثافة التكوين،

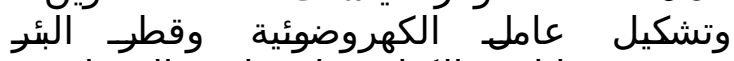
وتستخدم بيانات الكثافة لحسترول الحساب المسامية

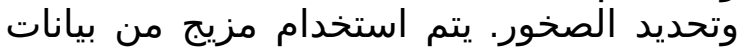
سجل النيوترونات والكثافة والتعويض الليدريد من للإشارة إلى وجود الهيدروكربون إن إنيون

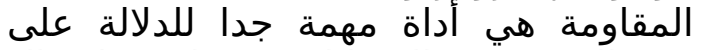
محتوى الصخورمن السوائل عن طريقة إلميقال إرسال

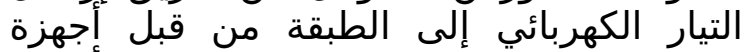

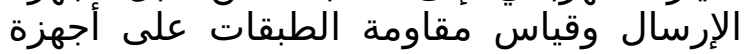

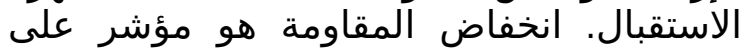

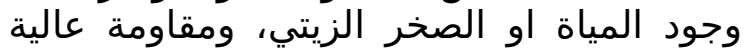

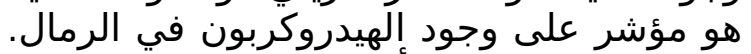

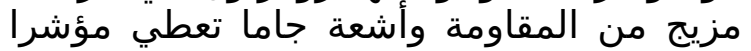
جيدا جدا على الغاز الموجود في في طبقات المات الرمال

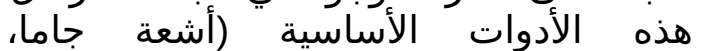

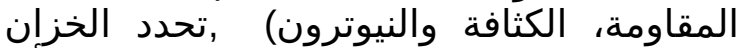
التقليدي بطريقة جيدة، ولكنها لا تستطيع أندان

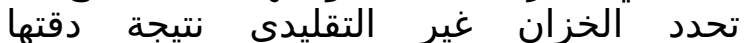
المنخفضة، ولتحديد هذا الخدان الخزاًن الغير تقليدي لابد من استخدام ادوات متقدمة ذات دقة عالة اليد 
DETECTION OF HYDROCARBON, BY USING ADVANCED ...

مثل والمتقدمة مثل اداة قياس الضغط وادوبور وادوات

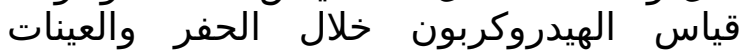

الصخرية التقليدية

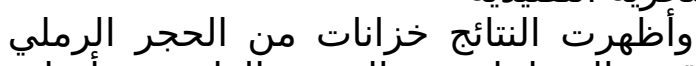

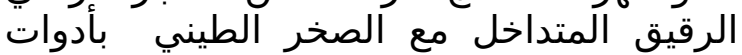

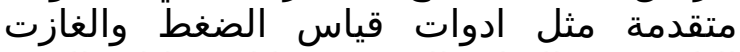

الناتجه من الفتات الصخري خلات ملال عمليات الحفر

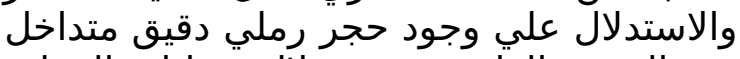

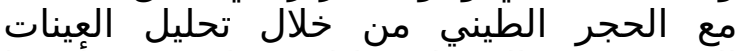

الصخرية في المعمل تحليلا دقيقاوسوف نأخذاتها

في الاعتبار هذة الطبمبات المبات ليتم الانتاج منها في في

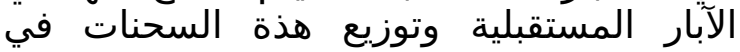

النموذج الساكن والنموذج الديناميكي لمضاهية الماتهات

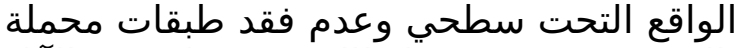

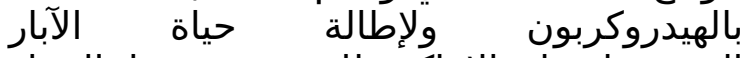

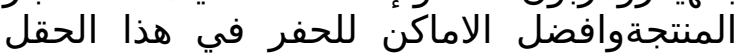

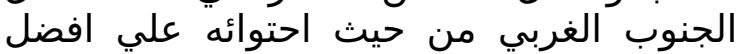

المعملات البتروفزيائيه 